\title{
CQUniversity, Australia
}

\section{Donna Lee Brien and Lynda Hawryluk}

\section{Facilitiating 'storied relationships to a place': The capacity of the university to lead communities towards resilience through creative arts activities}

\begin{abstract}
:
This article reports on the leadership aspects of the community creative arts based Resurfacing Stronger project, which was mounted in response to the recent flood crisis in Queensland, Australia, and involved the participation of a regional university. The project combines creative writing workshops and the publication of community writing with a study of contemporary community writing in Central Queensland. These various components are focused on gaining an understanding of the social dimensions of flood preparedness and response through creative writing as both action and product, as well as conducting a pilot study of contemporary community writing in the Central Queensland region. This article demonstrates the capacity of the university to lead communities towards resilience through creative arts activities, in this case, through leading community members in writing narratives of their individual relationships to localised places in times of crisis - what nature writer Barry Lopez has referred to as 'storied relationship[s] to a place' (1997).
\end{abstract}

\section{Biographical notes:}

Professor Donna Lee Brien is Professor of Creative Industries in the School of Creative and Performing Arts at CQUniversity, Australia. Founding Editor of dotlit: The Online Journal of Creative Writing, Donna is currently Special Issues Editor for TEXT: The Journal of Writing and Writing Courses, and the a Past President of the Australasian Association of Writing Programs.

Dr Lynda Hawryluk is a Lecturer in Literary and Cultural Studies at CQUniversity, where she teaches undergraduate creative writing subjects and supervises Masters of Letters and $\mathrm{PhD}$ students. Lynda has been coordinating the Idiom 23 Writers' Workshops on North Keppel Island since 2005 and has facilitated many writing workshops in the Central Queensland region.

\section{Keywords:}

Creative writing - Community engagement - Crisis responsive projects - Community writing workshops 


\section{Introduction}

Place, a sense of belonging to certain locations, and how these shape identity, feature in many discussions of mental and community health (Kearns \& Gesler 1998; Macintyre, Ellaway \& Cummins 2002). Place can form the locus of a range of personal, physical and emotional issues, including concerns about identity, happiness, health and self-esteem (see, for example, Kearns \& Gesler 1998), and it also grounds global discussions about sustainability and even the viability of life on earth (Thompson 2007). Many have drawn attention to the relationship between experience, place and identity (see, for instance, Lippard 1997; Tuan 1977, 2001). The term 'place attachment' describes the depth of this relationship (Altman \& Low 1992), and this connection forms the basis for the study of the idea of place in cultural anthropology (Lawrence \& Low 1990). With the increased mobility that has characterised Western life after the Second World War, an individual's relationship with place has become increasingly complex. It is known that this relationship becomes especially strained during times of natural disaster (Fullilove 1996).

Place also inspires and animates cultural and artistic production. The expression of the links between place and identity in writing is often known as 'the literature of place' (Lopez 1997) and Welty has usefully, and famously, described how 'every story would be another story, and unrecognizable as art, if it took up its characters and plot and happened somewhere else' (1978: 122). Lopez develops this to posit that 'writing that takes into account the impact nature and place have on culture is one of the oldest - and perhaps most singular - threads' in literature and that that 'the real topic' of both non-fiction and fiction writing about place is not the locale per se, but the changing structure of communities and their identities in those places (1997: $n p$ ).

This article reports on the leadership aspects of an academic led, creative arts based project, the Resurfacing Stronger project, mounted by the authors of this article in response to the recent flood crisis in Central Queensland in north-eastern Australia, at a time when inhabitants in that area had an just undergone an intense experience of the place they inhabited. The project combines place-focused community creative writing workshops and the publication of this community writing with a study of a specific place and its writing, that is, contemporary community writing in Central Queensland. Our aim in this project is twofold: to try to gain an understanding of the social dimensions of natural disaster - in this case flood - preparedness and response; as well as to use local writing as a way into identifying and describing community identity in relation to place.

\section{Background: flooding in Queensland}

During the summer of 2010/11, flooding was widespread in Central Queensland from the end of November 2010 to January 2011, with numerous roads - including nine major highways - closed, some communities isolated and/or evacuated, and a number of localities inundated more than once. Worse than this, there were significant losses of property (both residential and rural), disruptions to the coal and cattle industries (ABC News 2011, Chambers 2011) and forced evacuations (Flood Commission Witness Statement 2011). Residents of the Central Queensland area experienced 
isolation for significant periods of time as all roads and the airport were closed (Morning Bulletin 2011a, b \&c). There was no road transport in or out of the city of Rockhampton, one of the focal cities of the region, for almost three weeks, preventing the delivery of food supplies, and the airport was closed for two weeks (Gillham 2011; Formosa 2011; Greensill 2011a). In the closer outlying areas, such as Gracemere and Bouldercombe, roads were closed for up to four weeks, which not only prevented supplies getting in, but also commuters from reaching their workplaces in Rockhampton and elsewhere. Emerald was inundated with water and cut off for much of late December 2010 to early February 2011 (Courier Mail 2010), while the residents of Gogango were isolated on their properties west of Rockhampton for fourteen weeks (Burdon 2011).

Despite the extensiveness of the flooding, with reports that three quarters of the State had been declared a disaster zone in January 2011 (Hurst 2011) — and while certainly gathering national and international headlines, these inundations were not unique. Flooding is a regular event in the Central Queensland region, with some fifty previously recorded occasions of flooding of the Fitzroy River (affecting Rockhampton) alone, and three previous 'significant' flood events, in 1918, 1954 and 1991 (Webster 2003:1), where a significant flood event is considered to be inundation over the height of 9.0 metres. The Australian Bureau of Statistics notes that 'usually, the great Fitzroy and Burdekin river basins of Queensland receive flood rains during the summer wet season ... This widespread rain may cause floods over an extensive area, but it soon seeps away or evaporates' (ABS 2000: 17). In the summer of $2010 / 2011$, however, this seepage and evaporation were not sufficient, with repeated heavy rain events contributing to a record river height of 9.2 metres (BOM 2011a). December 2010 was the wettest December on record for Queensland, with 2010 the wettest year in that State since records have been kept (BOM 2011b: 17).

Although not unique, these floods certainly tested the resilience of the inhabitants of the Central Queensland region. Moreover, at the very time that the floods were affecting them the most, a number of flooded-in residents unwittingly found themselves in the middle of a political media storm (Morning Bulletin 2010) by defying demands from authorities to leave their isolated homes (Jensen 2011). Stories of this standoff made national headlines; however, the attention of the media and much of the public concern it was attracting were then rapidly redirected, first southeast to the Grantham River tragedy, and then north to the threat posed by the Category 5 Cyclone Yasi (Kamenev 2011). Despite being out of the national spotlight, the flood crisis continued in Rockhampton. Localised flooding affected the evacuation centre in late January (Brisbane Times 2011), the sewage treatment plant was only fully operational by mid-February (Taylor 2011), and further road closures occurred well into March 2011 (Morning Bulletin 2011c), at which time the threat of flooding was ongoing (Greensill 2011b). The impact of the floods continued once the water receded, with the level of disruption experienced leading to anecdotal reports of increased family and economic tension (Skinner 2011). 


\section{Context: community resilience and natural disasters}

In this discussion, and in framing the Resurfacing Stronger project overall, we define community resilience in the context of natural disasters in three ways: the preparedness of a community in anticipating a natural disaster, and its ability to both deal with that disaster and to regain normalcy afterwards. The USA-based Community and Regional Resilience Institute defines resilience as 'the capability to anticipate risk, limit impact, and bounce back rapidly through survival, adaptability, evolution, and growth in the face of turbulent change' (2011). The institute's work focuses on both the time during the disaster event and afterwards:

When a community is truly resilient, it should be able to avoid the cascading system failures to help minimize any disaster's disruption to everyday life and the local economy. A resilient community is not only prepared to help prevent or minimize the loss or damage to life, property and the environment, but also it has the ability to quickly return citizens to work, reopen businesses, and restore other essential services needed for a full and swift economic recovery (CRRI 2011).

Norris et al. explore the metaphor implied when the word 'resilience', a scientific term describing 'the capacity of a material or system to return to equilibrium after a displacement', is applied to people (2008: 127). They describe how the power of the term lies in how it describes a material bending and bouncing back rather than breaking under stress, as well as how speedily the state of equilibrium is once again achieved (2008: 127).

There have been numerous studies of the necessity to build community resilience to meet the challenges of natural disasters (see, for instance, Gow \& Paton 2008; Jha et al. 2010). Such resilience is seen to be a means of community and individual protection from, especially, the mental and other health challenges of natural disasters (see, for instance, Merriman \& Browitt 1993). Most studies seem to agree that 'educating communities about disaster preparedness and response will greatly enhance community resiliency to natural disasters' (SDD 2008: 47); however, there appears to be little agreement about what this education should comprise, and who is best to deliver it, including whether the latter be local, state or federal government agencies; non-governmental, non-profit organisations; businesses; individuals with specialist training; or interested community members. In terms of the instruction itself, much of the focus is, properly, on practical matters. In the Central Queensland region, the Rockhampton Regional Council issues households with a natural disaster preparedness information booklet, Emergency Action Guide (RRC 2010), while the Preparing for Cyclones booklet (EMQ 2007) and a Cyclone Tracking Map (EMQ 2008) are available online. These supplement prominent signposting on major roads, such as the 'Don't Think It Won't Happen to You' campaign (SES 2010), a joint venture between local and state governments, the State Emergency Service, Queensland Fire and Rescue, and Emergency Management Queensland (RRC 2011). On the Capricorn Coast, these billboards advocate cyclone readiness; in nearby Rockhampton they focus on being prepared in the event of flooding. 


\section{The Resurfacing Stronger project}

Being aware of the dangers of natural disasters and being physically prepared for them focus on the disaster event itself and do not necessarily enable a community to deal with the aftermath of recovery and healing following such events (Freedy et al. 1994). In this context, the Resurfacing Stronger project is based on the broadly accepted premise that the creative arts can provide leadership in communities by assisting those communities in gaining social as well as cultural and economic benefits. In our particular case, we chose the creative writing workshop as a primary site for individual participation in a group activity that can build a sense of community identity and resilience (see, Guetzkow 2002). Through this workshop, we offered participants the opportunity to strengthen their personal skills of creative thinking and expression through writing about their flood experiences, while participating in a forum where they could meet and discuss their experiences with other community members. From our side of the project, we were looking to facilitate the above, as well as seeking to utilise the products of the workshops to explore the role of such activities in reforging and reasserting a sense of identity after, or because of, the recent flood crisis. We were also interested in the nature of that identity; that is, the way these regional writers see themselves and their communities.

As such, this project is one of a number of community arts activities conducted and/or currently active in the Central Queensland area related to the floods and mounted in an attempt to assist in recovery after those events. In February 2011, just a little over two weeks after the Rockhampton airport was reopened, Crossroads Arts Mackay facilitated an informal workshop over a weekend, followed by an exhibition launch the following Monday evening. The workshop outcomes included poetic soundscapes, experimental writing and hand-drawn and painted postcards. Local guerilla art group, Nature is Here, stenciled their eponymous slogan on the streets of Rockhampton with Fitzroy River mud in May, and a group of writers are currently collaborating on the 2011 Rockhampton Flood Artists' Book Project, a limited edition letterpress of stories and art work on high quality artists' rag paper. In other areas of the State, the aftermath of the floods is similarly being addressed via communitybased arts activities. In Theodore, a town on the Leichhardt Highway three hours west of Bundaberg that was entirely evacuated twice during the flood crisis, CQUniversity academics are investigating enhancing community resilience using the 'PhotoVoice' methodology in a project that asks participants to represent their community or individual points of view by taking photographs, discussing them and developing accompanying narratives (PhotoVoice 2011). ${ }^{2}$

Using writing as the foundation media for creative expression in the Resurfacing Stronger project is valid as there is both a rich tradition and a vibrant contemporary culture of community writing in the Central Queensland region. The (now nonoperational) Central Queensland University Press has played an important role in encouraging traditional, experimental and community writing (Bennett 2007) in the region, as have the literary magazine Idiom 23 (published since 1987) and annual activities such as the Bauhinia Literary Awards and regional writing workshops (including the North Keppel Island Writers workshops, run since the early 1990s), and less frequent masterclasses (Hawryluk 2010). 
Seeking both to link into, and extend, this network of writing activities, the Resurfacing Stronger project has two parts. The first, completed during 2011, was the series of community writing workshops held in Rockhampton and Emerald, where participants were helped to voice and record their stories about the recent floods, using fiction, poetry, non-fiction and song. In calling for workshop participants and facilitating these workshops, we took the broadest possible view of 'flood affected', defining this as anyone who was affected by the flooding in any way, rather than only those who were dramatically or tragically affected. Workshop participants included some with writing experience and others who did not think of themselves as creative writers. The outcomes of these workshops are being edited and published in print and online, with work from all participants included in these publications. Some works have already been completed and feature in a special online section of the Idiom 23 website (see, Resurfacing Stronger Project 2011). These works are introduced with a description of the project and a visual representation of the keywords generated from the workshop's creative brainstorming sessions, when participants were asked to contribute their perceptions of the general reaction to the floods in their area, their own feelings about the floods, and their thoughts on the perceptions of those outside the community. A series of photographic images generated during the workshops and donated by participants is also being added to this site (see, Resurfacing Stronger Project 2011).

The second part of this project is a wholly university-funded research component that uses the materials generated in these workshops to investigate local community identity, in particular in relation to a sense of place and the recent flood crisis, and to map this against other community writings from Central Queensland. We are, firstly, analysing the content of these writings to assist in understanding the social dimensions of flood preparedness and response in our region, as well as the attendant issue of the mental health and allied health consequences of such events, findings which we will share with the community as detailed below. Secondly, these writings will form the foundation for a pilot study of contemporary community writing in Central Queensland.

\section{Leading sustainable partnerships}

In Central Queensland, community arts activities are supported by the relevant local council through grants from their Regional Arts Development Funds (RADF). RADF grants are awarded to selected projects that can demonstrate they are 'supporting locally determined arts and cultural practices' in ways that develop individual, regional and community arts capacity (RADF Guidelines 2008: 4, see RRC 2008). Utilising the official community validation that funding under this scheme offered ${ }^{3}$, and with financial and other support from our university, we are, through this project, seeking to provide leadership in our local community of writers in a number of ways. This is by using the data this project generates to develop and define new professional descriptors for these writers (that is, beyond the broad nomenclature of "community writer"), as well as ways to describe and evaluate the value and impact of their work to the community. 
Built into the research plan and budget is also the dissemination of the findings from the project both locally, in community-based activities, and further afield. This includes a university-funded public symposium to discuss the regional literature of place in 2012, which aims to bring together all the community writers from the workshops with other writers in the region as well as scholars from both inside and outside the local area. This will assist in addressing a substantial gap in local (as well as national) knowledge about how community writing and publishing contribute to an emergent field of inquiry internationally - the literature of place and regional community identity (see, Duxbury \& Campbell 2011) - and potentially provide a prototype for an ongoing public discussion forum on this topic.

This is important, for although there are many studies of place and space in relation to the work of major international writers, the study of regional literatures of place (or even regional literatures in themselves) has been much less common outside of the USA (see, for instance, Van Santvoort et al. 2008) and, to a lesser extent, the UK where the Centre for Regional Literature and Culture was launched in 2005 to 'interrogate the concepts of regionality and provincialism and explore the interactions between regional and national identities' (CRLC 2011: np). In Australia, the recognition and study of regional literatures really only began in the 1980s (Henningsgaard 2007). This study has tended to be from the perspectives of the different States with, for instance, at least eight State-based literature anthologies published in Queensland since 1980 (Bennett 1998; Henningsgaard 2007). Yet, this was often an idea of regionalism which was understood as any location outside of Melbourne and Sydney, with the majority of Queensland writers included in these anthologies living in its capital city, Brisbane, or hailing from rural and regional areas but working from other capital cities or overseas. Central Queensland writing and writers have not been well represented in these and other collections. This is also true of recent online collections: the State Library of Queensland's extensive online repository of digital stories includes only one story from Central Queensland, from Mount Morgan (SLQld 2011). Aside from Cryle's '(Re) Writing Traditions: The bush ethos in Central Queensland writing' in Buckridge and McKay's By the Book: A Literary History of Queensland Writing (2007) and a number of excellent local studies in decades past (MacDonald et al 1988a \& b; Hoare 1992; Huf et al. 1993; Huf 1996), there are few contemporary studies of local writers, community writing or the influence of writing activities on community identity or wellbeing in the Central Queensland region. This is also the case elsewhere in Australia and, in this context, it is hoped that the Resurfacing Stronger project will also contribute to local writers gaining an enhanced understanding of their own identities as writers, and providing local governments with a sense of the contribution these writers make to their communities.

\section{Concluding remarks}

In supporting the workshops, Dr Sue Rice, the Manager of Family Relationship Services for professional community social services provider Centacare in Rockhampton, has written that this project is 'an important part of the suite of 
recovery options available for the community, especially for people that may not ordinarily engage with counseling or other mainstream therapeutic interventions' (2011). Feedback from the workshops was overwhelmingly positive, and it was interesting that the writing generated was generally optimistic in tone, forward looking and, at times, humorous, suggesting a high level of resilience either mobilised, or developed, in the months after the floods.

From our perspective, we have found that these writing workshops, in terms of the products they have generated, have provided a valuable set of data for our associated ongoing research project. The stories, poems and songs produced are revealing patterns and trends in Central Queensland writing and contributing valuable information to consider in relation to the construction and reconstruction of community identity during times of crisis, and are also suggesting ways of researching regional creative arts practice more generally. Once formalised, this information potentially will, we hope, have real value for the community that has contributed to it.

Using engagement activities to generate research data is not a new methodology; however, it can be a one-way and even exploitative activity. By utilising a creative arts, practice-based approach that involves community members in various stages of the project as active creators (in the workshops) and critical contributors (in the symposium) rather than only as subjects of investigation, we have tried to take a leadership role in both our community and our university by imaging our local writers as professional creative artists (even if only emerging or just emergent) with past and future creative and personal aspirations, rather than solely focussing on their work as research data. By including our participants actively in the dissemination stages of the research project, we are, furthermore, hoping to also build these participants' capacity to engage in research activities unconnected to this project. This is an example of how we are using this project as a means of translating into practice our belief that universities have both the resources and knowledge, as well as a responsibility, to offer members of their local communities ongoing opportunities for personal, professional and creative development. The 'storied relationships to a place' (Lopez 1997) generated by this project already, of course, have a vibrant and valuable life as works of literature, separate to this project.

\section{Endnotes}

1. This phrase is from Barry Lopez's essay 'A literature of place' (2007).

2. Less interactively, a broad overview response to the flood experience was provided by ABC radio and print media journalists in the promptly produced book Flood: stories and images from the ABC of survival, loss and courage during the Queensland floods (ABC 2011), all proceeds of which went directly to the Premier's Disaster Relief Appeal.

3. The project is categorised in the 'Contemporary Collections/Stories' rubric, and seeks to service the key requirements of the guidelines for that category, with the writing workshops and publications generated from the project able to 'collect and tell stories from the past and present that can demonstrate State and/or local significance' as well as able to 'demonstrate strong community participation and ownership (RRC 2008). 


\section{Works cited}

ABC News 2011 'Rising floods bring fears for livestock' 5 January, at http://www.abc.net.au/news/2011-01-05/rising-floods-bring-fears-for-livestock/1894666 (accessed 5 July 2011)

Altman, I \& SM Low (eds) 1992 Place attachment New York: Plenum Press

(ABS) Australian Bureau of Statistics 2000 Year book Australia 82 Canberra: Commonwealth of Australia

Bennett, B 1998 'Literary culture since Vietnam: a new dynamic' in B Bennett and J Strauss (eds) The Oxford literary history of Australia Melbourne: Oxford University Press

Bennett, B 2007 'Review: Patrick Buckridge and Belinda McKay By the book: a literary history of Queensland' Journal of the Association for the Study of Australian Literature 7, 107-11

(BOM) Bureau of Meteorology 2011a Flood warning system for the Fitzroy River 2011, at http://www.bom.gov.au/hydro/flood/qld/brochures/fitzroy/fitzroy.shtml (accessed 5 July 2011)

(BOM) Bureau of Meteorology 2011b Annual climate summary 2010 Barton: Commonwealth of Australia, at http://www.bom.gov.au/climate/annual_sum/2010/AnClimSum10_LR1.0.pdf (accessed 16 September 2011)

Brisbane Times, 2011 'Minor flooding at Rockhampton evacuation centre' Brisbane Times 20 January, at http://www.brisbanetimes.com.au/queensland/minor-flooding-at-rockhampton-evacuationcentre-20110120-19x04.html (accessed 5 July 2011)

Burdon, D 2011 '14 Weeks isolated by river' The Morning Bulletin 3 March, at http://www.themorningbulletin.com.au/story/2011/03/03/14-weeks-isolated-by-river (accessed 5 July 2011)

Carter, P 2004 Material thinking: the theory and practice of creative research Melbourne: Melbourne University Press

Chambers, M 2011 'Coking coal prices to skyrocket as stockpiles dry up' The Australian 24 January, at http://www.theaustralian.com.au/business/coking-coal-prices-to-skyrocket-as-stockpiles-dryup/story-e6frg8zx-1225993253543 (accessed 5 July 2011)

Courier Mail, The 2010 'Queensland flood crisis forces about 4,000 from homes in Emerald, Rockhampton and Condamine' The Courier Mail 31 December, at http://www.couriermail.com.au/news/queensland-flood-crisis-forces-more-than-4000-people-fromhomes-in-emerald-rockhampton/story-e6freon6-1225979019781 (accessed 5 July 2011)

(CRCL) Centre for Regional Literature and Culture 2011 Nottingham: University of Nottingham, at http://www.nottingham.ac.uk/crlc (accessed 5 July 2011)

(CRRI) Community and Regional Resilience Institute 2011 Definition of community resilience: what is resilience?, at http:/www.resilientus.org/about-us/definition-of-community-resilience.html (accessed 5 July 2011)

Cryle, D 2007 '(Re) Writing traditions: the bush ethos in Central Queensland writing' in P Buckridge and B McKay (eds) By the book, a literary history of Queensland writing St Lucia: University of Queensland Press, 143-62

Duxbury, N \& H Campbell 2011 'Developing and revitalizing rural communities through arts and culture' Small cities imprint 3: 1, at http://smallcities.tru.ca/index.php/cura/article/view/39 (accessed 5 July 2011)

(EMQ) Emergency Management Queensland 2007 Preparing for cyclones, at http://www.emergency.qld.gov.au/emq/css/pdf/English_Cyclone\%20Book_11 oct07.pdf (accessed 5 July 2011)

(EMQ) Emergency Management Queensland 2008 Cyclone tracking map, at http://www.emergency.qld.gov.au/emq/css/pdf/cyclone_tracking_map.pdf (accessed 5 July 2011) 
(EMQ) Emergency Management Queensland 2010 SES Get ready guide, at http://www.emergency.qld.gov.au/emq/css/pdf/SES_Get_Ready_Guide\%202010.pdf (accessed 5 July 2011)

Flood Commission Witness Statement 2011 Statement of witness Inspector David William Peff, at http://www.floodcommission.qld.gov.au/_ data/assets/file/0020/7904/Peff_David_William.PDF (accessed 5 July 2011)

Formosa, A 2011 'Sigh of relief as groceries arrive' The Morning Bulletin 15 January, at http://www.themorningbulletin.com.au/story/2011/01/15/collective-sign-of-relief-as-groceries-beginto-ar (accessed 5 July 2011)

Freedy, JR, ME Saladin, DG Kilpatrick, HS Resnick and BE Saunders 1994 'Understanding acute psychological distress following natural disaster' Journal of traumatic stress 7: 2, 257-73

Fullilove, MT 1996 'Psychiatric implications of displacement: contributions from the psychology of place' American journal of psychiatry 153, 1516-23

Gillham, A 2011 'Rocky nearly isolated as flood crisis grows' Townsville Bulletin 4 January, at http://www.townsvillebulletin.com.au/article/2011/01/04/197271_news.html (accessed 5 July 2011)

Gow, K \& D Paton (eds) 2008 The phoenix of natural disasters: community resilience, New York: Nova Science Publishers

Greensill, K 2011a 'Highway to Rocky reopens to all traffic' The Morning Bulletin 14 January, at http://www.themorningbulletin.com.au/story/2011/01/14/bruce-highway-to-open-today (accessed 5 July 2011)

Greensill, K 2011 b 'Big wet not over in Central Qld' The Morning Bulletin 26 March, at http://www.themorningbulletin.com.au/story/2011/03/26/big-wet-rain-central-queenslandrockhampton (accessed 5 July 2011)

Guetzkow, J 2002 How the arts impact communities: an introduction to the literature on arts impact studies Report prepared for the Taking the Measure of Culture conference, Princeton University 7-8 June 2002

Henningsgaard, P 2007 'Regional literature and "the liminal": exploring the spaces in-between national and international literatures' Limina: a journal of historical and cultural Studies Special edition: On the Beach 2007, 12-19

Hurst, Daniel 2011 'Three-quarters of Queensland a disaster zone' Brisbane Times 11 January, at http://www.brisbanetimes.com.au/environment/weather/threequarters-of-queensland-a-disaster-zone20110111-19mf8.html\#ixzzlatkYb416 (accessed 9 July 2011)

Hoare, V (ed) 1992 Twenty years of women poets of Rockhampton Writers Club Rockhampton: The Club

Huf, L 1996 The Rockhampton Writers' Club 1966-1996: Its writers-its history Rockhampton: Central Queensland University Publications

Huf, L, L McDonald \& D Myers (eds) 1993 Sin, sweat and sorrow: the making of Capricornia, Queensland 1840s-1940s Rockhampton: University of Central Queensland Press; 1999 Rockhampton: Central Queensland University Press

Idiom 23 1988-current Rockhampton: Capricornia Institute, Humanities and Social Sciences; current Rockhampton, Central Queensland University

Jensen, E 2011 'A way of life for the proud swampers' Sydney Morning Herald 8 January, at http://www.smh.com.au/national/a-way-of-life-for-the-proud-swampers-20110107-19ito.html (accessed 5 July 2011)

Jha, AK, JD Barenstein, PM Phelps, D Pittet \& S Sena 2010 Safer homes, stronger communities: $a$ handbook for reconstructing after natural disasters Washington: The international Bank for Reconstruction and Development/The World Bank

Kamenev, M 2011 'Cyclone batters flood weary Queensland' Time 3 February, at http://www.time.com/time/world/article/0,8599,2045908,00.html (accessed 5 July 2011) 
Kearns, RA \& WM Gesler (eds) 1998 Putting health into place: landscape, identity, and well-being Syracuse: Syracuse University Press

Lawrence, DL \& SM Low 1990 'The built environment and spatial form' Annual review of anthropology 19, 453-505

Lippard, L 1997 The lure of the local: senses of place in a multicentered society New York: The New Press

Lopez, B 1997 'A literature of place' Portland magazine 16: 2, 22-5, at http://arts.envirolink.org/literary_arts/BarryLopez_LitofPlace.html (accessed 5 July 2011)

Macintyre, S, A Ellaway \& S Cummins 2002 'Place effects on health: how can we conceptualise, operationalise and measure them?' Social science \& medicine 55: 1, 125-39

MacDonald, E, V Hoare \& M Birkbeck (eds) 1988a 2,200 years under Capricorn 2 vols. Rockhampton: Rockhampton Writers' Club

MacDonald, E, V Hoare \& M Birkbeck (eds) 1998b Looking back (1988-1788): a bicentennial record of the Rockhampton Writers' Club Rockhampton: Rockhampton Writers' Club

Merriman, PA \& CWA Browitt (eds) 1993 Natural disasters: protecting vulnerable communities London: Royal Society and Thomas Telford Books

Morning Bulletin, The 2010 'Desperation grips Depot Hill locals' The Morning Bulletin 31 December, at http://www.themorningbulletin.com.au/story/2010/12/31/desperation-grips-depot-hill-locals-flood (accessed 5 July 2011)

Morning Bulletin, The 2011a 'Cut off for at least once more week' The Morning Bulletin 8 January, at http://www.themorningbulletin.com.au/story/2011/01/08/rockhampton-flood-cut-off-one-more-week (accessed 5 July 2011)

Morning Bulletin, The 2011b 'Flights resume into Rocky' The Morning Bulletin 24 January, at http://www.themorningbulletin.com.au/story/2011/01/24/flights-resume-into-rockhampton (accessed 5 July 2011)

Morning Bulletin, The 2011c ‘Flash flood closes highway’ The Morning Bulletin 25 March, http://www.themorningbulletin.com.au/story/2011/03/25/flash-flood-closes-bruce-flood-closurehighway (accessed 5 July 2011)

Norris, FH, SP Stevens, B Pfefferbaum, KF Wyche \& RL Pfefferbaum 2008 'Community resilience as a metaphor, theory, set of capacities, and strategy for disaster readiness' American journal of community psychology 41, 127-150

PhotoVoice 2011 Participatory photography for social change, at http://www.photovoice.org (accessed 5 July 2011)

Resurfacing Stronger Project, The 2011 Idiom 23, at http://idiom23.cqu.edu.au/FCWViewer/view.do?page=15171 (accessed 11 October 2011)

Rice, S 2011 Personal correspondence, July, Rockhampton

(RRC) Rockhampton Regional Council 20082008 RADF guidelines, at http://www.rockhamptonregion.qld.gov.au/Your_Community/Grants_and_Sponsorship/Regional_Arts _Development_Fund_RADF (accessed 5 July 2011)

(RRC) Rockhampton Regional Council 2010 Emergency action guide, at http://www.rockhamptonregion.qld.gov.au/files/468e6c20-3606-4918-ae2f-9db200ffdd98/RRC_ Emergency_Action_Guide.pdf, at Disaster management http://www.rockhamptonregion.qld.gov.au/Council_Services/Disaster_Management (accessed 5 July 2011)

(RRC) Rockhampton Regional Council 2011 Don't be complacent with disaster management: be prepared - natural disasters happen DVD launch 15 October 2010, at http://www.rockhamptonregion.qld.gov.au/Council_Services/News_and_Announcements/Latest_New s/Don\%E2\%80\%99t_be_complacent_with_disaster_management (accessed 5 July 2011) 
Santvoort, LV, J De Maeyer \& T Verschaffel (eds) 2008 Sources of regionalism in the nineteenth century: architecture, art, and literature Ithaca, NY: Cornell University Press

Skinner, G 2011 Personal correspondence, 11 July

Social Development Division (SDD) 2008 Enhancing community resilience to natural disasters: lives of children and youth in Aceh-discussion paper Indonesia: United Nations Economic and Social Commission for Asia and the Pacific

State Library of Queensland (SLQ) 2011 Queensland stories, at http://qldstories.slq.qld.gov.au/home/storylines\#Central\%20and\%20West (accessed 5 July 2011)

Taylor, A 2011 'Sewer system up and running' The Morning Bulletin 14 February, athttp://www.themorningbulletin.com.au/story/2011/01/24/flights-resume-into-rockhampton (accessed 5 July 2011)

Thompson, PB 2007 Food biotechnology in ethical perspective Dordrecht, Netherlands: Springer

Tuan, Y 2001 Space and place: the perspective of experience Minneapolis: University of Minnesota Press, 1st pub. 1977

Webster, B 2003 Marooned: Rockhampton's great flood of 1918 Brisbane: CRC for Coastal Zone Estuary \& Waterway Management

Welty, E 1978 The eye of the story, New York: Random House

\section{Acknowledgements}

The authors thank Dr Rosemary Williamson and the anonymous TEXT referees for their helpful suggestions on this paper, and acknowledge the contribution of the community members who participated in the project discussed. Responsibility for any problems in the paper rests with the authors. 